RASĀYAN J. Chem.

Vol. 13 | No. 4 |2455-2465| October - December | 2020 ISSN: 0974-1496 | e-ISSN: 0976-0083 | CODEN: RJCABP

\title{
MAIN FATTY ACIDS, PHENOLIC COMPOUNDS, AND EVALUATION OF GASTROPROTECTIVE EFFECT OF MALBEC GRAPE SEEDS, A WINE INDUSTRY BY-PRODUCT
}

\author{
Miki Gonzales-Uscamayta ${ }^{1, *}$, Juana E. Chávez-Flores², Henry Obregón- \\ Tinoco $^{3}$, Fiorella P. Cardenas-Toro ${ }^{3}$, Mario J. Simirgiotis ${ }^{4}$, Jorge Borquez ${ }^{5}$ \\ and Juana Robles-Caycho ${ }^{1}$ \\ ${ }^{1}$ Sección de Química, Departamento de Ciencias, Pontificia Universidad Católica del Perú, Av. \\ Universitaria 1801, San Miguel, Lima 32, Peru \\ ${ }^{2}$ Centro de Investigación Farmacéutica, Universidad Norbert Wiener, Av. Arequipa 440, \\ Lima, Peru \\ ${ }^{3}$ Sección de Ingeniería Industrial, Departamento de Ingeniería, Pontificia Universidad Católica \\ del Perú, Av. Universitaria 1801, San Miguel, Lima 32, Peru \\ ${ }^{4}$ Instituto de Farmacia, Facultad de Ciencias, Universidad Austral de Chile, Campus Isla Teja, \\ Valdivia 5090000, Chile \\ ${ }^{5}$ Laboratorio de Productos Naturales, Departamento de Química, Facultad de Ciencias \\ Básicas, Universidad de Antofagasta, Av. Universidad de Chile 02800, Antofagasta, Chile \\ *E-mail:m.gonzalesu@pucp.edu.pe
}

\begin{abstract}
Grape seeds are the main winemaking by-product, which has a high content of bioactive compounds. This study aims to evaluate the profile of fatty acids and phenolics of grape seeds (an organic waste), obtained from a Peruvian wine factory; the antioxidant activity and the gastroprotective effect of alcoholic extracts were also determined. The oil extraction yield was $14.8 \%$, mainly composed of linoleic $(71.6 \%)$ and oleic $(17.4 \%)$ acids. Furthermore, 22 phenolic compounds in the methanolic extract were identified by UHPLC-Q/Orbitrap/MS/MS, being the flavan-3-oles and procyanidins the major components. The content of phenolics and the antioxidant activity $\left(\mathrm{IC}_{50}\right)$ were $40.03 \pm 0.36$ $\mathrm{mg}$ of GAE/g of dry seed and $15.31 \pm 0.03 \mu \mathrm{g} / \mathrm{mL}$ respectively. The methanolic extract of grape seeds exhibited a great gastroprotective effect against gastric ulcers induced by naproxen, achieving $80 \%$ inhibition at a dose of 600 $\mathrm{mg} / \mathrm{kg}$. Base on the results, the grape seeds are a potential source of bioactive compounds, and their use is an alternative for the prevention of gastric ulcers.

Keywords: Grape Seeds, Fatty Acids, Phenolic Compounds, UHPLC-Q/Orbitrap/MS/MS, Gastroprotective Effect. (C) RASĀYAN. All rights reserved

\section{INTRODUCTION}

The grape (Vitis vinifera) is used mainly for the production of wine, and its oily seeds and leaves have applications in herbal medicine, the food industry and cosmetics. ${ }^{1}$ In Peru, in recent years, grape production has grown steadily ${ }^{2}$ and therefore the wine and pisco industry as well, this progress is accompanied by the generation of organic wastes. The pomace (composed of seed, peel and stem) is the main winemaking byproduct, which contains a high quantity of bioactive compounds. ${ }^{3}$ Seeds, for example, contain between 8$20 \%(\mathrm{w} / \mathrm{w})$ of oil (rich in unsaturated fatty acids) and 10 to $20 \%(\mathrm{w} / \mathrm{w})$ of phenolics. ${ }^{3,4}$ These variations in bioactive compound content mainly depend on genetic factors, soil, climate and viticulture. ${ }^{5}$

Many health benefits have been attributed to bioactive compounds such as polyunsaturated fatty acids, in the prevention of cardiovascular diseases, rheumatoid arthritis, post-infarction arrhythmias, breast and prostate cancer, ${ }^{6}$ and the inhibition of melanin production by melanocytes. ${ }^{7}$ Similarly, phenolics have been also reported to have antibacterial, antifungal, antiviral, platelet antiaggregant, hepatoprotective ${ }^{8,9}$ and gastroprotective properties. ${ }^{10}$
\end{abstract}

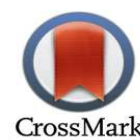


Gastric ulcers, a worldwide known disease, are mainly caused by Helicobacter pylori infection, the prolonged use of nonsteroidal anti-inflammatory drugs (NSAIDs), alcohol consumption, and cigarette smoking. ${ }^{11,12}$ To prevent and treat gastric ulcers, many gastroprotective drugs have been developed. However, despite their benefits, many side effects have been attributed to their long-term usage, which includes the recurrence of ulcers. ${ }^{12}$ Therefore, other alternative remedies are needed. Interestingly, some phenolic compounds, especially flavonoids, such as naringenin, quercetin, myricetin rhamnoside and rutin have been shown to be effective in suppressing or modulating gastric ulcers. ${ }^{13}$

Based on the development of the new products with greater added value from agricultural and industrial residues, it has been proved to have both a positive environmental and economic impact. ${ }^{14}$ However, because of the limited information published about local sources of bioactive compounds; further investigation is needed to characterize compounds of interest in organic residues such as pomace. Therefore, this study aimed to determine the content of fatty acids, phenolic compounds, antioxidant activity and evaluation of the gastroprotective effect of grape seeds, coming from a Peruvian wine factory.

\section{Reagents}

\section{EXPERIMENTAL}

All analytical grade reagents such as FAMES NLEA Mix 28 components (Resteck), ascorbic acid, gallic acid, 2,2-diphenyl-1-picrilhidrazil, Folin Ciocalteu, HPLC solvents (methanol, chloroform), hexane, butanol and acetic acid were purchased from SIGMA ALDRICH (Lima, Peru); ranitidine and naproxen were purchased from Farmindustria (Lima, Peru).

\section{Sample Preparation}

The Malbec grape residues (pomace), composed of seed and peel, were donated by Santiago Queirolo Wine Company (Lima, Peru). The selection of seeds from the pomace was done manually, then dried at $45^{\circ} \mathrm{C}$ until constant weight and finally, the material was crushed using an electric grinder (Bosch, model MKM6003). The ground grape seeds were stored at $0{ }^{\circ} \mathrm{C}$ for further analysis.

\section{Oil Extraction}

The oils extraction was executed by two methods: Soxhlet (S) extraction, $10 \mathrm{~g}$ of pulverized seed were weighed, extracted with $60 \mathrm{~mL}$ of hexane for $4 \mathrm{~h}$, and then the solvent was removed with a rotary evaporator at $45{ }^{\circ} \mathrm{C}$. Also, the supercritical fluids (SCF) extraction with $\mathrm{CO}_{2}$ as a solvent was based on the method developed by Obregón et al., ${ }^{15}$ the supercritical fluid extractor STF-150 (Supercritical Fluid Technology, USA) belonging to ITEPA (Investigación en Tecnología de Procesos Agroindustriales) research group. The extraction of $30 \mathrm{~g}$ of seed $\left(388.14 \mu \mathrm{m}\right.$ particle) with supercritical $\mathrm{CO}_{2}$ at a flow of $5 \mathrm{ft}^{3} / \mathrm{h}, 456 \mathrm{bar}, 50{ }^{\circ} \mathrm{C}$ and $30 \mathrm{~min}$ was performed.

\section{Fatty Acid Methyl Esters (FAMEs) Preparation and GC-FID Analysis}

The FAMEs were obtained following the method proposed by Fiori et al. ${ }^{16}$ with some modifications. The reaction was carried out in a basic medium, by adding $10 \mathrm{~mL}$ of $0.5 \mathrm{M} \mathrm{KOH}$ (in methanol) to grape seed oil (0.3-0.5 g), at $65-70{ }^{\circ} \mathrm{C}$ for $3 \mathrm{~h}$ with constant stirring. Finally, $15 \mathrm{~mL}$ of hexane was added twice and dried. FAMEs obtained were analyzed by gas chromatography (GC-FID, model 7890A) equipped with DB23 column $(30 \mathrm{~m} \times 0.25 \mathrm{~mm} \times 0.25 \mu \mathrm{m})$, a split injector at $250{ }^{\circ} \mathrm{C}$, ionization detector at $300{ }^{\circ} \mathrm{C}$. Hydrogen was used as a carrier gas and the split ratio was $30 \mathrm{~mL} / \mathrm{min}$. The column temperature program was 5-100 ${ }^{\circ} \mathrm{C}(12 \mathrm{~min})$ at $5{ }^{\circ} \mathrm{C} / \mathrm{min}, 100-150{ }^{\circ} \mathrm{C}(5 \mathrm{~min})$ at $10{ }^{\circ} \mathrm{C} / \mathrm{min}, 150-230{ }^{\circ} \mathrm{C}(18 \mathrm{~min})$ at $20^{\circ} \mathrm{C} / \mathrm{min}$. A solution of $1500 \mathrm{mg} / \mathrm{L}$ of FAMEs was used as a standard of methyl esters. The fatty acids were identified by comparison of retention times with the standard.

\section{Profile of Phenolic Compounds by UHPLC-Q/Orbitrap/MS/MS}

The phenolic profile determination was made according to the methodology proposed by Simirgiotis et al. ${ }^{17}$ Five mg of defatted dry methanolic extract was weighed, dissolved with $5 \mathrm{~mL}$ of cold methanol and filtered through a $0.45 \mu \mathrm{m}$ microporous membrane (PTFE). The analysis was carried out in UHPLC equipment with a PDA detector coupled to ESI-Orbitrap-MS (with electrospray ionization), belonging to the Natural 
RASĀYAN J. Chem.

Vol. 13 | No. 4 |2455-2465| October - December | 2020

Products Laboratory of the University of Antofagasta (Chile). The separation by UHPLC was done with a C18 column (Acclaim, $150 \mathrm{~mm}, 4.6 \mathrm{~mm}$ ID, $5 \mu \mathrm{m}$ ) conditioned at $25^{\circ} \mathrm{C}$. The gradient system, consisting of a mobile phase A ( $1 \%$ formic aqueous solution) and $\mathrm{B}$ (acetonitrile), was $5 \% \mathrm{~B}(0-5 \mathrm{~min}), 5-30 \% \mathrm{~B}(5$ $\mathrm{min}), 30 \% \mathrm{~B}(5 \mathrm{~min}), 30-70 \% \mathrm{~B}(5 \mathrm{~min}), 70 \% \mathrm{~B}(5 \mathrm{~min})$ and $70-5 \% \mathrm{~B}(10 \mathrm{~min})$. The flow rate and the injection volume was $1 \mathrm{~mL} / \mathrm{min}$ and $10 \mu \mathrm{L}$ respectively. The HESI and Orbitrap spectrometer parameters in a negative mode were previously optimized by Simirgiotis et al. ${ }^{17}$ The Thermo Xcalibur software was used to process the data.

\section{Total Phenolic Content and Antioxidant Activity}

Phenolic compounds were extracted by maceration of $10 \mathrm{~g}$ of defatted seed meal with $50 \mathrm{~mL}$ of methanol (three times) at room temperature. The extracts obtained were pooled, filtered and evaporated to dryness for storage. The quantification of total phenols was performed using the Folin Ciocalteu method. ${ }^{18}$ An aliquot of methanolic extract of $1 \mathrm{mg} / \mathrm{mL}$ concentration was mixed with $450 \mu \mathrm{L}$ of Folin Ciocalteu, $4 \mathrm{~mL}$ of $7.5 \% \mathrm{Na}_{2} \mathrm{CO}_{3}$, and was diluted with distilled water up to $10 \mathrm{~mL}$. The reaction time was $1 \mathrm{~h}$ at room temperature and the absorbance was measured at $765 \mathrm{~nm}$. A solution of gallic acid of $1 \mathrm{mg} / \mathrm{mL}$ was used as a standard. All measurements were done in triplicate and the results were expressed in $\mathrm{mg}$ of gallic acid equivalent (GAE) per gram of dry seed.

The antioxidant activity was evaluated in vitro with 2,2-diphenyl-1-picrilhidrazil method. ${ }^{19} 3 \mathrm{~mL}$ of a 20 ppm DPPH solution (in methanol) was added to volumes between 10 and $60 \mu \mathrm{L}$ of methanolic extract solution of $1 \mathrm{mg} / \mathrm{mL}$, the mixture was diluted up to $4 \mathrm{~mL}$ with methanol. The reaction time was $2 \mathrm{~h}$ at room temperature and the absorbance was read at $515 \mathrm{~nm}$. The same process was repeated with a standard of ascorbic acid solution $(1 \mathrm{mg} / \mathrm{mL})$. The $\mathrm{IC}_{50}$ values were estimated by plotting the measured absorbance against the concentrations of the solutions used in the assay.

\section{Gastroprotective Effect Evaluation of Methanolic and Butanolic Extract}

The gastroprotective effect was conducted using methanolic and butanolic grape seed extracts, following the naproxen-induced gastric ulcer model. Holtzman strain rats (180-280 g of weight) acquired in the bioterium of the Faculty of Sciences of the Cayetano Heredia University (Lima, Peru) were used. The methanolic extract was obtained by maceration of $150 \mathrm{~g}$ of dry seed meal with methanol, then it was defatted with hexane and chloroform; half of the resulting methanolic extract was fractionated with butanol giving as result the butanolic extract; finally, both methanolic and butanolic extracts were dried $\left(45^{\circ} \mathrm{C}\right)$ and ground. The pharmacological study was performed with 63 rats, which were divided into 9 groups (three females and four males) and conditioned for five days, before the test. The tested treatments are shown in Table-1, all of them were administered orally. The procedure was initiated with rats subjected to $24 \mathrm{~h}$ of fasting. Rats set in group 1 were treated with water only and those set in group 2 were treated with naproxen. Group 3 was treated with ranitidine for an hour, then with naproxen for five hours; in the same way, groups from 4 to 9 were first treated with the correspondent extract and then with naproxen. Details of the exposure time of the animals to each treatment are summarised in the protocol of gastroprotective effect evaluation (Fig.-1). At the end of the trial, rats' stomachs were extracted for the corresponding macroscopic analysis of the lesions produced in the mucous and muscular layer using the modified Marhuenda scale ${ }^{20}$.

The data was performed by SPSS (Statistical Package for the Social Sciences) version 23, 2018. The results were expressed in terms of percent inhibition according to the following equation.

Where:

$$
\text { Inhibition } \left.\%=\frac{\mathrm{P} \text { mean of IGU }-\mathrm{P} \text { mean of TG }}{\mathrm{P} \text { mean of IGU }} \times 100 \quad \text { (equation } 1\right)
$$

P: average obtained in the macroscopic evaluation according to scale

IGU: induced gastric ulceration group by naproxen

TG: treatment group

Table-1: Treatments Applied to Determine the Gastroprotective Effect in Rats.

\begin{tabular}{c|c}
\hline Group & Treatment Description \\
\hline 1. Negative control & Distilled water $1 \mathrm{~mL} / 100 \mathrm{~g}$ weight \\
\hline 2. Naproxen & Naproxen sodium $550 \mathrm{mg} / \mathrm{kg}$ \\
\hline
\end{tabular}


RASĀYAN J. Chem.

Vol. 13 | No. 4 |2455-2465| October - December | 2020

\begin{tabular}{c|c}
\hline 3. Ranitidine & Ranitidine (standard drug) $150 \mathrm{mg} / \mathrm{kg}+$ naproxen $550 \mathrm{mg} / \mathrm{kg}$ \\
\hline $4 . \mathrm{MeOH}-200$ & Methanolic extract $200 \mathrm{mg} / \mathrm{kg}+$ naproxen $550 \mathrm{mg} / \mathrm{kg}$ \\
\hline $5 . \mathrm{MeOH}-400$ & Methanolic extract $400 \mathrm{mg} / \mathrm{kg}+$ naproxen $550 \mathrm{mg} / \mathrm{kg}$ \\
\hline $6 . \mathrm{MeOH}-600$ & Methanolic extract $600 \mathrm{mg} / \mathrm{kg}+$ naproxen $550 \mathrm{mg} / \mathrm{kg}$ \\
\hline $7 . \mathrm{BuOH}-200$ & Butanolic extract $200 \mathrm{mg} / \mathrm{kg}+$ naproxen $550 \mathrm{mg} / \mathrm{kg}$ \\
\hline $8 . \mathrm{BuOH}-400$ & Butanolic extract $400 \mathrm{mg} / \mathrm{kg}+$ naproxen $550 \mathrm{mg} / \mathrm{kg}$ \\
\hline $9 . \mathrm{BuOH}-600$ & Butanolic extract $600 \mathrm{mg} / \mathrm{kg}+$ naproxen $550 \mathrm{mg} / \mathrm{kg}$ \\
\hline
\end{tabular}

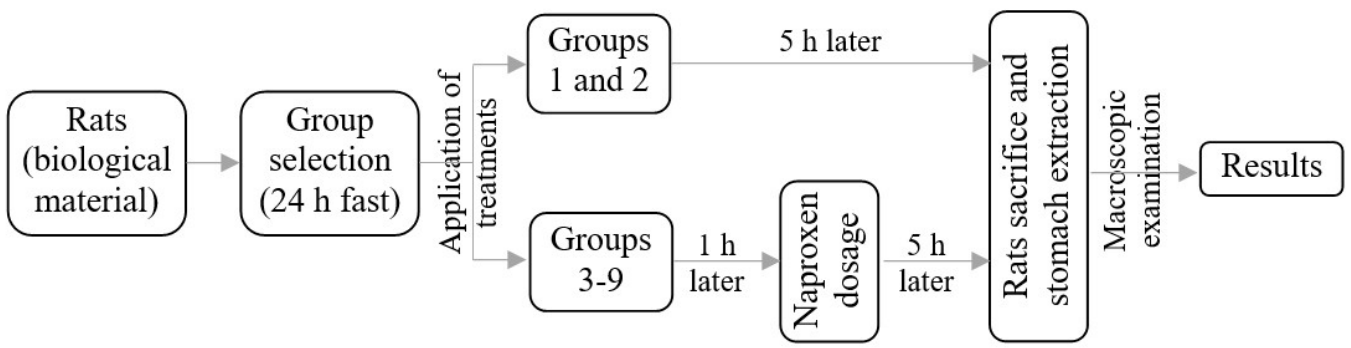

Fig.-1: Protocol for the Evaluation of the Gastroprotective Effect.

\section{Fatty Acids Determination}

RESULTS AND DISCUSSION

The best percentage of seed oil recovery was obtained using the Soxhlet (S) method, which was $14.8 \%$. This value is within the range of 7.6-16.0\% and $11.1-16.6 \%$ reported by Maier et al. ${ }^{21}$ and Fiori et al. ${ }^{16}$ respectively for grape seeds. In the supercritical $\mathrm{CO}_{2}(\mathrm{SCF})$ extraction, the recovery was only $8.2 \%$, which is close to the range of values of $10.1-15.0 \%$ reported by Fiori et al. ${ }^{16}$ The percentage of the transesterified fraction concerning the weight of crude oil for both S and SCF were 13.5 and $25.8 \%$ respectively. These results suggest that $\mathrm{S}$ shows a good oil extraction performance, while SCF is more selective because of its high content of transesterified material. The fatty acid composition in grape seeds was determinate by GCFID, the results for both S and SCF oil extraction methods are shown in Table-2. Linoleic acid was the most abundant fatty acid (for both methods), with an average value of $71.6 \%$, followed by oleic acid (17.4\%); significant amounts of palmitic acid (6.6\%) and stearic acid (4.3\%) were also found. No significant differences were observed in the composition of fatty acids in the grape seed oil extracted by both methods. Also, the fatty acid profile for grape seed oil from the Malbec variety is the same, however, the small variations in quantities are mainly related to the origin of the grape as shown in Table- 2 .

Table-2: Comparison of the Extraction Yield and Fatty Acid Composition of Malbec Grape Seed Oil.

\begin{tabular}{l|c|c|c|c|c}
\hline \multirow{2}{*}{ Grape Seed Oil } & \multicolumn{2}{|c|}{ Experimental } & \multicolumn{3}{c}{ Reported Values } \\
\cline { 2 - 6 } & $\mathrm{S}$ & $\mathrm{SCF}$ & $\mathrm{S}^{22}(\mathrm{a})$ & $\mathrm{SCF}^{22}(\mathrm{a})$ & $\mathrm{SCF}^{23}(\mathrm{~b})$ \\
\hline Yield (\%) & 14.8 & 8.2 & 10.8 & 9.4 & 13.4 \\
\hline Transesterification (\%) & 13.5 & 25.8 & -- & -- & -- \\
\hline Fatty acid composition (\%) & 6.4 & 6.8 & 6.4 & 6.3 & 8.1 \\
\hline Palmitic acid & 4.4 & 4.2 & 4.7 & 4.7 & 4.1 \\
\hline Stearic acid & 17.3 & 17.5 & 19.0 & 18.5 & 15.1 \\
\hline Oleic acid & 71.9 & 71.4 & 66.8 & 67.6 & 71.2 \\
\hline Linoleic acid & & &
\end{tabular}

Grape Seeds from (a) Canada and (b) Brazil.

\section{Metabolomics Profile by UHPLC-Q/Orbitrap/MS/MS}

The phenolic compounds in the extract were identified or tentatively characterized by verifying the retention time and mass fragmentation. The identified compounds are shown in Table-3, which includes retention time, tentative compound, metabolite type, elementary composition $[\mathrm{M}-\mathrm{H}]^{-}$, theoretical and experimental 
RASĀYAN J. Chem.

Vol. 13 | No. 4 |2455-2465| October - December | 2020

$m / z$, accuracy (ppm) and the fragments found. The Orbitrap analysis allowed to identify 22 phenolic compounds (a hydroxybenzoic acid, 6 phenolic acids, 2 flavanonols, a flavonol and 12 flavan-3-oles) and 6 organic acids.

Table-3: Phenolic Compounds Identified in Grape Seeds by UHPLC-Q/Orbitrap/MS/MS.

\begin{tabular}{|c|c|c|c|c|c|c|c|}
\hline $\begin{array}{c}\text { Peak } \\
\#\end{array}$ & $\begin{array}{c}\mathrm{Rt} \\
(\mathrm{min})\end{array}$ & Tentative identification & $\begin{array}{l}\text { Molecular } \\
\text { formula } \\
{[\mathrm{M}-\mathrm{H}]^{-}}\end{array}$ & $\begin{array}{c}\text { Theoretical } \\
\text { mass } \\
(\mathrm{m} / \mathrm{z})\end{array}$ & $\begin{array}{c}\text { Measured } \\
\text { mass }(m / z)\end{array}$ & $\begin{array}{c}\text { Precision } \\
\text { (ppm) }\end{array}$ & $\begin{array}{c}\mathrm{MS}^{2} \text { ion } \\
\text { mass } \\
(\mathrm{ppm})\end{array}$ \\
\hline 1 & 2.07 & Gluconic acid $^{24}$ & $\mathrm{C}_{6} \mathrm{H}_{11} \mathrm{O}_{7}^{-}$ & 195.0510 & 195.0507 & 1.74313 & $\begin{array}{l}177.0398 \\
159.0293 \\
151.0605 \\
129.0185 \\
\end{array}$ \\
\hline 2 & 2.35 & Malic acid ${ }^{25}$ & $\mathrm{C}_{4} \mathrm{H}_{5} \mathrm{O}_{5}^{-}$ & 133.0143 & 133.0134 & 6.51810 & 115.0027 \\
\hline 3 & 2.44 & Citric acid ${ }^{25}$ & $\mathrm{C}_{6} \mathrm{H}_{7} \mathrm{O}_{7}^{-}$ & 191.0197 & 191.0193 & 2.09403 & $\begin{array}{l}147.0292 \\
111.0079\end{array}$ \\
\hline 4 & 3.40 & Succinic acid ${ }^{25}$ & $\mathrm{C}_{4} \mathrm{H}_{5} \mathrm{O}_{4}^{-}$ & 117.0193 & 117.0186 & 6.08447 & ND \\
\hline 5 & 3.51 & Galloyl hexose I ${ }^{25}$ & $\mathrm{C}_{13} \mathrm{H}_{15} \mathrm{O}_{10}{ }^{-}$ & 331.0671 & 331.0669 & 0.42288 & $\begin{array}{l}169.0135 \\
125.0236\end{array}$ \\
\hline 6 & 4.29 & Gallic acid ${ }^{26}$ & $\mathrm{C}_{7} \mathrm{H}_{5} \mathrm{O}_{5}^{-}$ & 169.0143 & 169.0138 & 2.94058 & 125.0236 \\
\hline 7 & 9.38 & $(+)$-catechin-3-O-hexoside 27 & $\mathrm{C}_{21} \mathrm{H}_{23} \mathrm{O}_{11}^{-}$ & 451.1246 & 451.1246 & 0.03325 & $\begin{array}{l}289.0715 \\
245.0455 \\
151.0391\end{array}$ \\
\hline 8 & 9.98 & $\begin{array}{c}\text { O-hexoside syringic } \\
\text { acid }^{25}\end{array}$ & $\mathrm{C}_{15} \mathrm{H}_{19} \mathrm{O}_{10}^{-}$ & 359.0984 & 359.0986 & 0.72404 & $\begin{array}{l}125.0236 \\
197.0448\end{array}$ \\
\hline 9 & 10.08 & $(+)$-Gallocatechin ${ }^{5}$ & $\mathrm{C}_{15} \mathrm{H}_{13} \mathrm{O}_{7}^{-}$ & 305.0667 & 305.0664 & 0.77360 & $\begin{array}{l}221.0454 \\
179.0343 \\
167.0344 \\
\end{array}$ \\
\hline 10 & 10.38 & Astilbine I 28 & $\mathrm{C}_{21} \mathrm{H}_{21} \mathrm{O}_{11}^{-}$ & 449.1089 & 449.1089 & 0.04453 & $\begin{array}{l}303.0506 \\
275.0539 \\
151.0393 \\
\end{array}$ \\
\hline 11 & 10.41 & (-)-Epigallocatechin ${ }^{5}$ & $\mathrm{C}_{15} \mathrm{H}_{13} \mathrm{O}_{7}^{-}$ & 305.0667 & 305.0664 & 0.97028 & $\begin{array}{l}221.0453 \\
179.0343 \\
167.0346\end{array}$ \\
\hline 12 & 10.47 & Procyanidin B3 ${ }^{29}$ & $\mathrm{C}_{30} \mathrm{H}_{25} \mathrm{O}_{12}^{-}$ & 577.1352 & 577.1342 & 1.61141 & $\begin{array}{l}451.1031 \\
425.0874 \\
407.0768 \\
289.0713 \\
\end{array}$ \\
\hline 13 & 10.49 & $\begin{array}{l}\text { Vanillic acid } \\
\text { glycoside } 25,28\end{array}$ & $\mathrm{C}_{14} \mathrm{H}_{17} \mathrm{O}_{9}^{-}$ & 329.0878 & 329.0883 & 1.37957 & $\begin{array}{l}167.0342 \\
123.0440\end{array}$ \\
\hline 14 & 11.03 & $(+)$-Catechin 26,30 & $\mathrm{C}_{15} \mathrm{H}_{13} \mathrm{O}_{6}^{-}$ & 289.0718 & 289.0717 & 0.34594 & $\begin{array}{l}245.0451 \\
151.0393\end{array}$ \\
\hline 15 & 11.10 & p-cumaric acid 26,30 & $\mathrm{C}_{9} \mathrm{H}_{7} \mathrm{O}_{3}^{-}$ & 163.0401 & 163.0393 & 4.83317 & 119.0493 \\
\hline 16 & 11.13 & Syringic acid ${ }^{30}$ & $\mathrm{C}_{9} \mathrm{H}_{9} \mathrm{O}_{5}{ }^{-}$ & 197.0456 & 197.0449 & 3.50173 & $\begin{array}{l}181.0501 \\
153.0549\end{array}$ \\
\hline 17 & 11.25 & Procyanidin B1 29 & $\mathrm{C}_{30} \mathrm{H}_{25} \mathrm{O}_{12}{ }^{-}$ & 577.1352 & 577.1343 & 1.40348 & $\begin{array}{l}451.1031 \\
425.0875 \\
407.0769 \\
289.0714\end{array}$ \\
\hline 18 & 11.33 & Ferulic acid ${ }^{26}$ & $\mathrm{C}_{10} \mathrm{H}_{9} \mathrm{O}_{4}^{-}$ & 193.0506 & 193.0498 & 4.30975 & $\begin{array}{l}179.0341 \\
149.0600\end{array}$ \\
\hline
\end{tabular}


RASĀYAN J. Chem.

Vol. 13 | No. 4 |2455-2465| October - December | 2020

\begin{tabular}{|c|c|c|c|c|c|c|c|}
\hline 19 & 11.44 & Astilbine II 28 & $\mathrm{C}_{21} \mathrm{H}_{21} \mathrm{O}_{11}^{-}$ & 449.1089 & 449.1090 & 0.22266 & $\begin{array}{l}303.0507 \\
275.0559 \\
151.0393\end{array}$ \\
\hline 20 & 11.52 & $\begin{array}{c}\text { Dehydroepicatechin- } \\
\text { 3-gallate I }{ }^{28}\end{array}$ & $\mathrm{C}_{22} \mathrm{H}_{15} \mathrm{O}_{10}^{-}$ & 439.0671 & 439.0668 & 0.61494 & $\begin{array}{l}287.0559 \\
169.0137 \\
125.0236 \\
\end{array}$ \\
\hline 21 & 11.60 & (-)-Epicatechin ${ }^{26,30}$ & $\mathrm{C}_{15} \mathrm{H}_{13} \mathrm{O}_{6}^{-}$ & 289.0718 & 289.0716 & 0.48431 & $\begin{array}{l}245.0444 \\
151.0393\end{array}$ \\
\hline 22 & 11.84 & Procyanidin B4 29 & $\mathrm{C}_{30} \mathrm{H}_{25} \mathrm{O}_{12}{ }^{-}$ & 577.1352 & 577.1339 & 2.14854 & $\begin{array}{l}451.1031 \\
425.0877 \\
407.0771 \\
289.0714\end{array}$ \\
\hline 23 & 11.97 & $\begin{array}{l}\text { Dehydroepicatechin- } \\
3 \text {-gallate II isomer } 28\end{array}$ & $\mathrm{C}_{22} \mathrm{H}_{15} \mathrm{O}_{10}^{-}$ & 439.0671 & 439.0667 & 0.75159 & $\begin{array}{l}287.0555 \\
169.0136 \\
125.0236\end{array}$ \\
\hline 24 & 12.10 & $\begin{array}{l}\text { Myricetin } \\
\text { rhamnoside }^{31}\end{array}$ & $\mathrm{C}_{21} \mathrm{H}_{19} \mathrm{O}_{12}{ }^{-}$ & 463.0882 & 463.0878 & 0.79898 & $\begin{array}{l}317.0290 \\
289.0353 \\
193.0135 \\
\end{array}$ \\
\hline 25 & 12.45 & Procyanidin B2 29 & $\mathrm{C}_{30} \mathrm{H}_{25} \mathrm{O}_{12}{ }^{-}$ & 577.1352 & 577.1343 & 1.40348 & $\begin{array}{l}451.1031 \\
425.0876 \\
407.0764 \\
289.0715\end{array}$ \\
\hline 26 & 12.60 & $\begin{array}{l}\text { Epicatechin-3- } \\
\text { Gallate } 28,30\end{array}$ & $\mathrm{C}_{22} \mathrm{H}_{17} \mathrm{O}_{10}^{-}$ & 441.0827 & 441.0825 & 0.45343 & $\begin{array}{l}289.0714 \\
245.0447 \\
151.0393\end{array}$ \\
\hline 27 & 13.63 & Azelaic acid ${ }^{25}$ & $\mathrm{C}_{9} \mathrm{H}_{15} \mathrm{O}_{4}^{-}$ & 187.0976 & 187.0971 & 2.61895 & 143.1070 \\
\hline 28 & 19.89 & Quinic acid ${ }^{25}$ & $\mathrm{C}_{7} \mathrm{H}_{11} \mathrm{O}_{6}^{-}$ & 191.0561 & 191.0550 & 6.08198 & 147.0654 \\
\hline
\end{tabular}

ND: Not Detected

\section{Hydroxybenzoic Acids, Phenolics and Derivatives}

Compounds $6,15,16$ and 18, were identified as gallic, $p$-cumaric, syringic and ferulic acids respectively. The $m / z$ signals were detected at $125,119,153$ and 149 correspondings to the loss of the carboxyl group ($\mathrm{CO}_{2}$ ) of gallic, $p$-cumaric, syringic and ferulic acids. In addition to their molecular ion, in the case of the syringic and ferulic acid, the $\mathrm{m} / \mathrm{z}$ signals 181 and 179 were due to the loss of water, respectively. Compound 5 was characterized as glucogallin (Galloyl hexose I), formed by gallic acid and $\beta$-D-glucose. The $\mathrm{m} / z 169$ fragments, resulting from the loss of the glycoside group and $\mathrm{m} / z 125$ typical of the galloyl ion, were observed. On the other hand, compound 9 had the molecular ion $\mathrm{m} / \mathrm{z} 359$ and the fragments $\mathrm{m} / \mathrm{z} 197$ and 125 , which correspond to syringic acid glycoside. Compound 14 was identified as a vanillic acid glycoside because of the typical molecular ion $\mathrm{m} / z 329$ and fragments $\mathrm{m} / \mathrm{z} 167$ and 123. Most of these compounds were found in different grape varieties such as Tempranillo, Graciano, Cabernet Sauvignon, Merlot among others, ${ }^{26,28,30}$ but just some of them were found in Malbec variety. ${ }^{32}$

\section{Flavanonols}

Compounds 10 and 19 were identified as flavanonol-3-O-hexosides corresponding to isomers of astilbin (dihydroquercetin-3-O-rhamnoside), which are found in some red and white wines. ${ }^{28}$ The flavanonols showed the molecular ion $\mathrm{m} / \mathrm{z} 449$, and the presence of the fragment $\mathrm{m} / \mathrm{z} 303$ means the loss of the rhamnoside group (distinctive fragment). ${ }^{28}$ The signal $\mathrm{m} / \mathrm{z} 151$ is characteristic of the loss of CO within flavanonols fragmentation. Based on the fragments presented and due to the different retention times, it is concluded that both compounds are isomers.

\section{Flavonols}

Compound 24 was identified as myricetin rhamnoside, according to the mass of the molecular ion $\mathrm{m} / \mathrm{z} 463$ and the fragment $\mathrm{m} / \mathrm{z} 317$, indicative of the loss of a rhamnosyl unit. It should be noted that the presence of 
RASĀYAN J. Chem.

Vol. 13 | No. 4 |2455-2465| October - December | 2020

this compound, according to the chromatogram, is minimal compared to the others; its presence in grapes of Malbec variety has not been reported; while the Muscadinia variety has a high content. ${ }^{31}$

Compounds 7, 9, 11, 14, 20, 21, 23 and 26 with molecular ion masses $\left([\mathrm{M}-\mathrm{H}]^{-}\right) \mathrm{m} / z$ 451, 305, 305, 289, 439, 289, 439 and 441 were identified as (+)-catechin-3-hexoside, gallocatechin, epigallocatechin, catechin, dehydroepicatechin-3-gallate I, epicatechin, dehydroepicatechin-3-gallate II and epicatechin-3-gallate, respectively, all of them monomeric flavan-3-ols. Also, compounds 12, 17, 22 and 25 were identified as procyanidins B3, B1, B4 and B2 respectively, with molecular ion $m / z 577$. The differentiation between them was carried out by comparison of the elution order, previously reported. ${ }^{26,28,29}$

\section{Organic Acids}

Compounds 1, 2, 3, 4, 27 and 28 were characterized as gluconic, malic, citric, succinic, azelaic and quinic acids, respectively. Their identification was achieved by comparing their behavior in the mass spectrum with those of published literature ${ }^{24,25}$ and retention time. Fragments $m / z 151,147,143$ and 147 corresponded to compounds 1, 4, 28 and 29, respectively, and also were observed the products of the carboxyl group ($\mathrm{CO}_{2}$ ) loss of its precursor ions. On the other hand, the fragment $\mathrm{m} / z 115$ was observed for compound 2, a product of a water molecule loss, and, in the case of compound 4, the fragmentation could not be observed because its molecular ion weight was close to 100 (the Orbitrap only reports ions mass above that value).

\section{Total Phenolic Content and Antioxidant Activity}

The total phenolic content in grape seeds, determined by the Folin Ciocalteu method, gave a value of 40.03 $\pm 0.36 \mathrm{mg}$ of GAE/g of dry seed. Table-4 points out that analyzed seeds maintain a significant quantity of phenolic compounds compared to other grape seed varieties (regardless of their origin), even after the fermentation process (approximately 10-25 days) in wine production. Additionally, comparing this value with those reported in other unprocessed samples from different plant species, such as fruit pulp from Antidesma bunius L. (6.7 mg of GAE/g) ${ }^{33}$ and leaves from Allium schoenoprasum L. (111.3 $\mathrm{mg}$ of $\mathrm{GAE} / \mathrm{g}),{ }^{34}$ the level of phenolics in grape seeds is still significant.

Table-3: Variation of Total Phenolic Content in Some Grape Varieties with Different Sample Origin.

\begin{tabular}{|c|c|c|}
\hline Grape Seeds Variety & Sample Origin & mg GAE/g dry seed \\
\hline Chardonnay, Shiraz and others ${ }^{35}$ & Fresh fruit (unprocessed) & $47.2-86.6$ \\
\hline Cabernet Mitos, Lemberger and others ${ }^{21}$ & Winemaking residue & $107.4-226.0$ \\
\hline Merlot, Cabernet and others ${ }^{36}$ & Fresh fruit (unprocessed) & $79.2-154.6$ \\
\hline White grape ${ }^{37}$ & Winemaking residue & $14.7-66.8$ \\
\hline Syrah $^{38}$ & Winemaking residue & $15.6-22.6$ \\
\hline Malbec $^{32}$ & Fresh fruit (unprocessed) & $26.7-43.2$ \\
\hline
\end{tabular}

The antioxidant activity of grape seeds was evaluated by DPPH method. The percentages of maximum inhibition were as follows $95.3 \%$ for the methanolic extract was and $96.0 \%$ for the ascorbic acid (AA). In terms of $\mathrm{IC}_{50}$ (concentration required to inhibit $50 \% \mathrm{DPPH}$ radicals), the calculated values for both methanolic extract and AA were $15.31 \pm 0.03$ and $10.44 \pm 0.01 \mu \mathrm{g} / \mathrm{mL}$ respectively. This outcome indicates that the antioxidant capability of the methanolic extract is very close to the standard, which is consistent with the content and the variety of phenolics found in grape seeds.

\section{Gastroprotective Effect}

The gastroprotective effect of the extracts was evaluated using the naproxen-induced gastric ulcer model. The results of gastric lesions in rats' stomachs for each treatment are shown in Fig.-2, where can be observed the 4 of the 6 signs considered in the Marhuenda scale (Table-5). Fig.-2.1 shows the appearance of a healthy rat stomach. In the Fig.-2.2, the perforated ulcers (black spots), the loss of mucosal folds, edema and mucosal discoloration caused by naproxen can be observed. These signs were inhibited by ranitidine (Fig.2.2), except for the mucosa discoloration, which was partially inhibited. In the case of the extracts, an increase in dosage from 200 to $600 \mathrm{mg} / \mathrm{kg}$ led to an increase in their effectiveness in the reduction of gastric 
RASĀYAN J. Chem.

Vol. 13 | No. 4 |2455-2465| October - December | 2020

lesions. The observed lesions for each stomach were converted into punctuations according to the Marhuenda scale, then punctuations were replaced into equation 1 to obtain de inhibition percentage. The results demonstrated that methanolic extract at a dose of $600 \mathrm{mg} / \mathrm{kg}$ had the highest percentage of inhibition $(80.1 \%)$ and its effectiveness in the reduction of gastric lesions can be observed in the Fig.-2.4. In the same way, the butanolic extract achieved its maximum percentage of inhibition $(68.1 \%)$ at a dose of $600 \mathrm{mg} / \mathrm{kg}$; for this case, the partial reduction of ulceration intensity can be observed in Fig.-2.5. Finally, the inhibition percentages calculated for each treatment are given in Fig.-3, where the inhibitory tendency for both methanolic and butanolic extract was proportional to the dose applied. These results indicate that the grape seed extracts display an antiulcer activity, additionally, it is comparable to the percentage of inhibition exhibited by the hydroalcoholic extract from Achyrocline satureoides (86.2\%), a South American indigenous medicinal plant used in the treatment of gastritis. ${ }^{39}$

The gastroprotective effect also called antiulcer effect, is attributed to the presence of different organic compounds such as organic acids, phenolic compounds (mainly phenolic acids and flavonoids) and coumarins. ${ }^{10,13}$ This can be explained by the ability of phenolic compounds to interfere with the metabolism of prostaglandins, especially PGE2, which is responsible for the activation of EP1, EP3 and EP4 receptors, and, as a consequence, the hydrochloric acid secretion by the mucocitoprotector is inhibited. ${ }^{40}$

Our findings pointed out that butanolic extract, which was obtained by liquid-liquid partition from the methanolic extract to enrich the extract with phenolics, has less percentage of inhibition. It suggests the gastroprotective effect is due to the synergistic interaction between all compounds previously reported in Table-3. Therefore, the bioactive compounds from grape seeds, especially phenolics and organic acids, have a great gastroprotective effect.

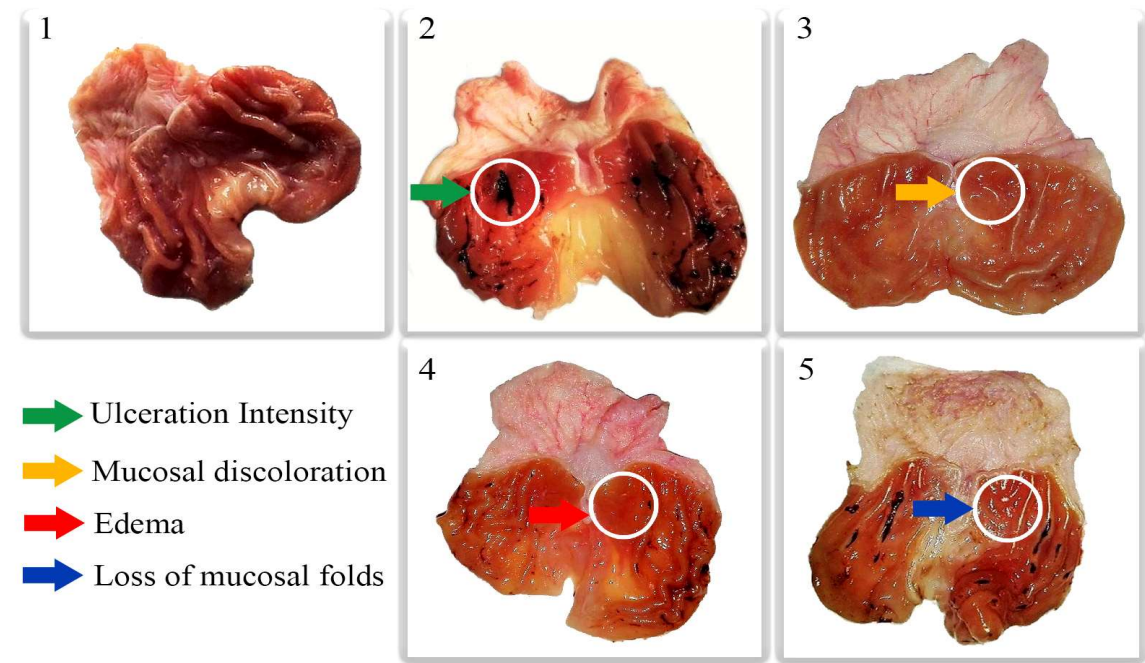

Fig.-2: Representative Images of Rats' Stomach after Treatment Application, (1) Negative Control, (2) Induced Gastric Ulcers by Naproxen, (3) Ranitidine, (4) Methanolic Extract at $600 \mathrm{mg} / \mathrm{kg}$ and (5) Butanolic Extract at 600 $\mathrm{mg} / \mathrm{kg}$

Table-5: Parameters of the Marhuenda Scale for the Evaluation of the Gastroprotective Effect.

\begin{tabular}{c|c|c|c|c}
\hline \multirow{2}{*}{ SIGNS } & \multicolumn{4}{|c}{ SCORE } \\
\cline { 2 - 5 } & 0 & 1 & 2 & 3 \\
\hline Loss of mucosal folds & does not present & presents & -- & -- \\
\hline Mucosal discoloration & does not present & presents & -- & -- \\
\hline Edema & does not present & presents & -- & -- \\
\hline Haemorrhages & does not present & presents & -- & -- \\
\hline Number of petechiae & none & from1 to 5 & from 5 to 10 & from 10 to 15 \\
\hline Ulceration Intensity & no ulcer & ulcer $<1 \mathrm{~mm}$ & ulcer $>1 \mathrm{~mm}$ & perforated ulcer \\
\hline
\end{tabular}


RASĀYAN J. Chem.

Vol. 13 | No. 4 |2455-2465| October - December | 2020

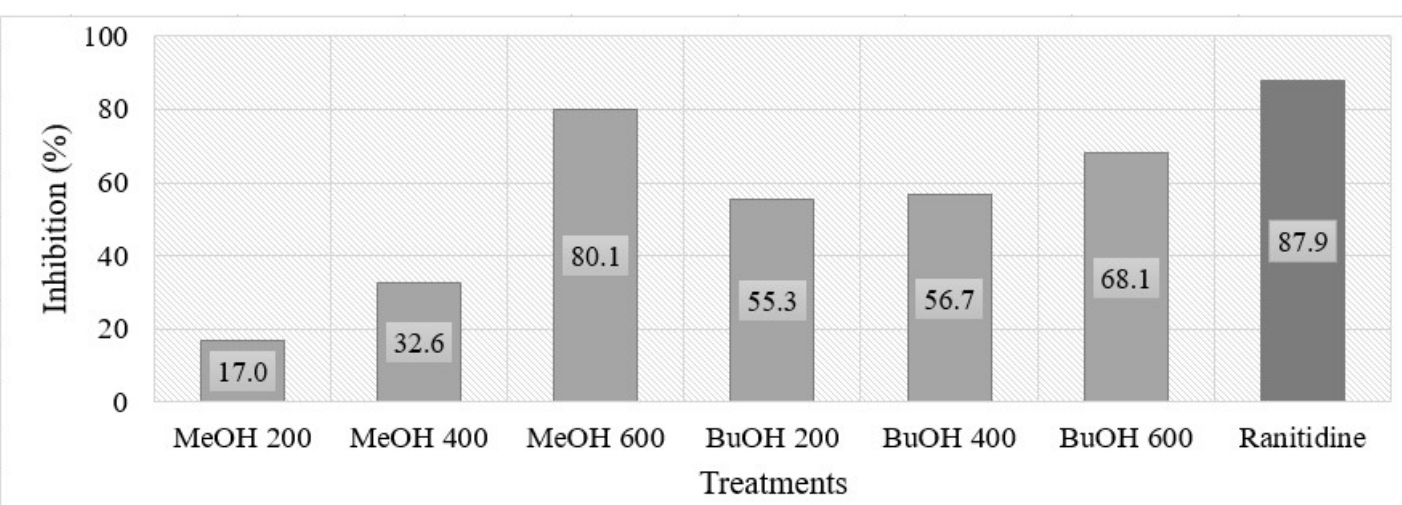

Fig.-3: Comparison of Percentage of the Inhibitory Effect of Methanolic and Butanolic Extracts from Grape Seeds against Ranitidine.

\section{CONCLUSION}

The main components from Malbec grape seeds, fatty acid and phenolic compounds, were successfully determined. Percentage of oil recovery using Soxhlet method extraction (yield 14.8\%) showed better than supercritical fluid method (yield 8.2\%). By UHPLC-Q/Orbitrap/MS/MS analysis 22 phenolic compounds were identified, mainly composed by flavan-3-oles and procyanidins. The total phenolic content of the methanolic extract was $40.03 \mathrm{mg}$ of GAE/g of dry seed with significant DPPH scavenging activity $\left(\mathrm{IC}_{50}=\right.$ $15.31 \pm 0.03 \mu \mathrm{g} / \mathrm{mL}$ ). The evaluation of gastroprotective effect of the methanolic and butanolic extracts in rats showed that the methanolic extract, at $600 \mathrm{mg} / \mathrm{kg}$ dose, proved to be the most effective, with an inhibition value of $80.1 \%$ of gastric lesions induced by naproxen. Our findings suggest that grape seeds, a by-product of winemaking, are a great source of bioactive compounds. Also, the use of grape seeds is an alternative for the prevention of gastric ulcers.

\section{ACKNOWLEDGEMENT}

Our special thanks to CONCYTEC (Consejo Nacional de Ciencia y Tecnología), Peru, for the grant that made possible this research.

\section{REFERENCES}

1. D. Fraternale, D. Ricci, G. Verardo, A. Gorassini, V. Stocchia and P. Sestili, Natural Product Communications, 10(6), 1037(2015), DOI:10.1177/1934578X1501000661

2. A. Ramirez-Hernandez, O.A. Galagarza, M.V. Álvarez Rodriguez, E. Pachari Vera, M.C. Valdez Ortiz, A.J. Deering and H.F. Oliver, Comprehensive Reviews in Food Science and Food Safety, 19(6), 3323(2020), DOI:10.1111/1541-4337.12647

3. S. Bail, G. Stuebiger, S. Krist, H. Unterweger and G. Buchbauer, Food Chemistry, 108(3), 1122(2008), DOI:10.1016/j.foodchem.2007.11.063

4. C. Da Porto, E. Porretto and D. Decorti, Ultrasonics Sonochemistry, 20(4), 1076(2013), DOI: 10.1016/j.ultsonch.2012.12.002

5. R. Perestrelo, Y. Lu, S.A.O. Santos, A.J.D. Silvestre, C.P. Neto, J.S. Câmara and S.M. Rocha, Food Chemistry, 135(1), 94(2012), DOI:10.1016/j.foodchem.2012.04.102

6. M. La Guardia, S. Giammanco, D. Di Majo, G. Tabacchi, E. Tripoli and M. Giammanco, Panminerva Medica, 47(4), 245(2005), Article ID: 16489323

7. H. Ando, A. Ryu, A. Hashimoto, M. Oka and M. Ichihashi, Archives of Dermatological Research, 290(7), 375(1998), DOI:10.1007/s004030050320

8. Purwantiningsih, N. Jannah and D.U.C. Rahayu, Rasayan Journal of Chemistry, 13(01), 322(2020), DOI:10.31788/RJC.2020.1315484

9. M. Jay, M.R. Viricel and J.F. Gonnet, 2005, C-Glycosylflavonoids, in: O.M. Andersen and K.R. Markham (Eds), Flavonoids: chemistry, biochemistry, and applications, CRC press, New York, pp. 858-903. 
RASĀYAN J. Chem.

Vol. 13 | No. 4 |2455-2465| October - December | 2020

10. M.T. Monforte, A. Smeriglio, M.P. Germanò, S. Pergolizzi, C. Circosta and E.M. Galati, Phytotherapy Research, 32(7), 1404(2018), DOI:10.1002/ptr.6078

11. H. Park, D. Cho, E. Huang, J.Y. Seo, W.G. Kim, S.D. Todorov, Y. Ji and W.H. Holzapfel, Frontiers in Microbiology, 11, 420(2020), DOI:10.3389/fmicb.2020.00420

12. B. Scally, J.R. Emberson, E. Spata, C. Reith, K. Davies, H. Halls, L. Holland, K. Wilson, N. Bhala, C. Hawkey, M. Hochberg, R. Hunt, L. Laine, A. Lanas, C. Patrono and C. Baigent, The Lancet Gastroenterology \& Hepatology, 3(4), 231(2018), DOI:10.1016/S2468-1253(18)30037-2

13. K.S. De Lira Mota, G.E.N. Dias, M.E.F. Pinto, A. Luiz-Ferreira, A.R. Monteiro Souza-Brito, C.A. Hiruma Lima, J.M. Barbosa Filho and L.M. Batista, Molecules, 14(3), 979(2009), DOI:10.3390/molecules 14030979

14. D. Dobravalskyte, B. Zebib, O. Merah and O. Ragažinskien, Records of Natural Products, 7(3), 201(2013), Article ID: hal-02649419

15. H. Obregón Tinoco, F. Huayta Socantaype and F. Cardenas Toro, Proceedings of the 16th LACCEI International Multi-Conference for Engineering, Education and Technology, Peru, (2018), DOI:10.18687/LACCEI2018.1.1.268

16. L. Fiori, V. Lavelli, K.S. Duba, P.S.C. Sri Harsha, H.B. Mohamed and G. Guella, The Journal of Supercritical Fluids, 94, 71(2014), DOI:10.1016/j.supflu.2014.06.021

17. M. Simirgiotis, C. Quispe, J. Bórquez, C. Areche and B. Sepúlveda, Molecules, 21(1), 92(2016), DOI:10.3390/molecules21010092

18. L. Yu, J. Perret, M. Harris, J. Wilson and S. Haley, Journal of Agricultural and Food Chemistry, 51(6), 1566(2003), DOI: 10.1021/jf020950z

19. I. Fidrianny, A. Rahmawati and R. Hartati, Rasayan Journal of Chemistry, 11(4), 1628(2018), DOI:10.31788/RJC.2018.1143091

20. E. Marhuenda, M.J. Martin and C.D.L Alarcon Lastra, Phytotherapy Research, 7(1), 13(1993), DOI:10.1002/ptr.2650070105

21. T. Maier, A. Schieber, D.R. Kammerer and R. Carle, Food Chemistry, 112(3), 551(2009), DOI:10.1016/j.foodchem.2008.06.005

22. T.H.J. Beveridge, B. Girard, T. Kopp and J.C.G. Drover, Journal of Agricultural and Food Chemistry, 53(5), 1799(2005), DOI:10.1021/jf040295q

23. J.M. Prado, I. Dalmolin, N.D.D. Carareto, R.C. Basso, A.J.A. Meirelles, J. Vladimir Oliveira, E.A.C. Batista and M.A.A. Meireles, Journal of Food Engineering, 109(2), 249(2012), DOI:10.1016/j.jfoodeng.2011.10.007

24. M.L. Cádiz-Gurrea, S. Fernández-Arroyo, J. Joven and A. Segura-Carretero, Food Research International, 50(1), 197(2013), DOI:10.1016/j.foodres.2012.09.038

25. I.M. Abu Reidah, M.M. Contreras, D. Arráez Román, A. Segura Carretero and A. Fernández Gutiérrez, Journal of Chromatography A, 1313, 212(2013), DOI:10.1016/j.chroma.2013.07.020

26. A. Baiano, M.A. Previtali, I. Viggiani and A. De Gianni, European Food Research and Technology, 242(6), 825(2016), DOI:10.1007/s00217-015-2588-6

27. E. Sommella, G. Pepe, F. Pagano, C. Ostacolo, G.C. Tenore, M.T. Russo, E. Novellino, M. Manfra and P. Campiglia, Food Research International, 76, 466 (2015), DOI:10.1016/j.foodres.2015.05.044

28. M. Monagas, R. Suárez, C. Gómez-Cordovés and B. Bartolomé, American Journal of Enology and Viticulture, 56(2), 139(2005).

29. M. Monagas, C. Gómez-Cordovés, B. Bartolomé, O. Laureano and J.M. Ricardo da Silva, Journal of Agricultural and Food Chemistry, 51(22), 6475(2003), DOI:10.1021/jf030325+

30. D. Kammerer, A. Claus, R. Carle and A. Schieber, Journal of Agricultural and Food Chemistry, 52(14), 4360(2004), DOI:10.1021/jf049613b

31. J.H. Lee, J.V. Johnson and S.T. Talcott, Journal of Agricultural and Food Chemistry, 53(15), 6003(2005), DOI: $10.1021 / \mathrm{jf050468 \textrm {r }}$

32. M. Fanzone, F. Zamora, V. Jofré, M. Assof and Á. Peña-Neira, Journal of Agricultural and Food Chemistry, 59(11), 6120(2011), DOI:10.1021/jf200073k

33. M. Yasser, M. Rafi, W.T. Wahyuni, S.E. Widiyanti and A.M.I.A. Asfar, Rasayan Journal of Chemistry, 13(01), 684(2020), DOI:10.31788/RJC.2020.1315584 
RASĀYAN J. Chem.

Vol. 13 | No. 4 |2455-2465| October - December | 2020

34. S.M. Sinaga, S. Sudarmi, I. Iksen, K. Kevin and M.P. Sari, Rasayan Journal of Chemistry, 11(4), 1604(2018), DOI:10.31788/RJC.2018.1144067

35. Y. Li, G.K. Skouroumounis, G.M. Elsey and D.K. Taylor, Food Chemistry, 129(2), 570(2011), DOI:10.1016/j.foodchem.2011.04.068

36. B. Bozan, G. Tosun and D. Özcan, Food Chemistry, 109(2), 426(2008), DOI:10.1016/j.foodchem.2007.12.056

37. A. Bucić-Kojić, M. Planinić, S. Tomas, M. Bilić and D. Velić, Journal of Food Engineering, 81(1), 236(2006), DOI: 10.1016/j.jfoodeng.2006.10.027

38. J.L. Marqués, G.D. Porta, E. Reverchon, J.A.R. Renuncioand and A.M. Mainar, The Journal of Supercritical Fluids, 82, 238(2013), DOI:10.1016/j.supflu.2013.07.005

39. J.R. Santin, M. Lemos, L.C. Klein Júnior, R. Niero and S. Faloni de Andrade, Journal of Ethnopharmacology, 130(2), 334(2010), DOI:10.1016/j.jep.2010.05.014

40. K. Takeuchi, 2010, Prostaglandin EP receptors and their roles in mucosal protection and ulcer healing in the gastrointestinal tract, in: G.S Makowski (ed.), Advances in clinical chemistry, Academic Press, USA, pp. 121-168.

[RJC-5955/2020] 